\title{
JEKK
}

Jurnal Epidemiologi Kesehatan Komunitas

4 (1), 2019, 18-26

\section{Faktor Risiko Kejadian Nefropati Diabetika pada Wanita}

\author{
Sri Wahyuningsih", HS Heri-Nugroho **, Suhartono ${ }^{* * *}$, Suharyo Hadisaputro ${ }^{* * *}$, Mateus Sakundarno \\ $\mathrm{Adi}^{* * *}$
}

"Kantor Kesehatan Pelabuhan Semarang, ${ }^{* *}$ Fakultas Kedokteran Universitas Diponegoro, ${ }^{* * *}$ Fakultas Kesehatan Masyarakat Universitas Diponegoro

\begin{abstract}
Background : Diabetic nephropathy was the most frequent complication in diabetics. The prevalence in women at South East Asia country was higher than men, that different than in Europe, American and African. It's be controversial thing. There was no reseacrh about the risk factors for diabetic nephropathy in women in Indonesia.

Methods : The purpose of this study was to determine the risk factors for stage 3-5 diabetic nephropathy in women. This research usesd case control study design. The cases were women with stage 3-5 diabetic nephropathy. Sampling by consecutive sampling technique by comparing the age of the case. Data were analyzed statistically by univariate, bivariate and multivariate using multiple logistic regression analysis.

Results : The results of the analysis showed that the risk factors for stage 3-5 diabetic nephropathy were hyperuricemia (OR:9.6; 95\%CI:1.870-45.799), lack of physical activity (OR:9.5; 95\%CI:1.693-53,287), blood sugar level $\geq 126$ mg/dl (OR:14.7; 95\% CI:1.487145.846), history of oral contraceptive use (OR:7.3; 95\%CI:1.254-42.716) and history of obesity (OR:8.9; 95\%CI:1.195-65.766).

Conclusion : It is recommended for diabetics people to control uric acid levels, fasting blood glucose, body weight and do enough physical activity. For oral contraceptives users it is recommended to consult with a doctor during consumption.
\end{abstract}

Keywords: Diabetic Nephropathy, Risk Factor, Women.

*Penulis korespondensi : sriwahyuningsih_r@yahoo.com 


\section{Pendahuluan}

Nefropati diabetika merupakan penyebab utama penyakit gagal ginjal kronik di Indonesia. ${ }^{1}$ Hal ini tidak hanya terjadi di Indonesia, di Singapura sekitar $60 \%$ gagal ginjal juga disebabkan oleh nefropati diabetika ${ }^{2}$, sedangkan di Oman dalam studi selama 3 dekade (tahun 19832013) menyebutkan nefropati merupakan penyebab kedua terbesar penyakit gagal ginjal yang menjalani cangkok ginjal $(28 \%)$ serta merupakan penyebab utama penyakit gagal ginjal yang menjalani hemodialisis $(46 \%){ }^{3}$ Nefropati diabetika menjadi penyebab utama morbiditas dan mortalitas pada diabetes baik tipe 1 maupun tipe 2 serta meningkatkan risiko penyakit kardiovaskuler terutama gagal jantung. 4,5

Studi di Singapura tahun 20072013 pada penderita penyakit ginjal diabetik menunjukkan annual mortality rate sebesar 64,1 per 1000 penderita per tahun, dan semakin meningkat seiring dengan peningkatan keparahan dari penyakit ginjal diabetic. ${ }^{6}$ Hasil studi di RSUD Kendal dan RSUD Tugurejo tahun 2016 menunjukkan bahwa $25,8 \%$ penderita gagal ginjal kronik yang menjalani dialisis disebabkan oleh diabetes. ${ }^{7}$ Jika penderita nefropati diabetika telah sampai pada stadium gagal ginjal, maka penatalaksanaan yang dapat dilakukan adalah dengan dialisis seumur hidup atau dengan trasnplantasi ginjal. ${ }^{8}$ Hal ini berakibat pada menurunnya kualitas hidup penderita dan biaya yang sangat besar. ${ }^{9}$

Nefropati diabetika didefinisikan sebagai tampilan klinis makro-albuminuria persisten atau mikro-albuminuria dan abnormalitas fungsi ginjal yang ditunjukkan oleh abnormalitas serum kreatinin. Hal ini dihitung dengan klirens kreatinin atau glomerular filtration rate (GFR) ${ }^{8}$

Prevalensi nefropati diabetika bervariasi dari berbagai negara. Prevalensi nefropati diabetika di Arab Saudi sebesar
$10,8 \%,{ }^{10}$ sedangkan hasil studi kohort di Kanada dari tahun 1990 sampai 2010 pada penderita diaebtes tipe 1 diperoleh angka insiden kumulatif sebesar 2,6\%, 6,3\% dan $11,9 \%$ selama 5,10 dan 15 tahun pengamatan. ${ }^{11}$ Prevalensi nefropati diabetika di negara-negara Asia lebih tinggi seperti di Malaysia $^{12}$ dan Singapura masing-masing mencapai $90,7 \%$ dan $52,5 \%{ }^{13}$

Hasil survei di puskesmas di Indonesia yang dilakukan pada tahun 2003 terhadap 770 pasien DM tipe 2 diperoleh angka prevalensi mikro/makro-albumin yang cukup tinggi yaitu $80 \%$ dan $36 \%$ dari 433 pasien mengalami insufisiensi ginjal. ${ }^{14}$ Penyakit diabetes melitus (DM) tipe 1 dan 2 yang berkembang menjadi nefropati diabetika sekitar 20\%-40\%.

Nefropati diabetika dapat dicegah dengan mengelola faktor-faktor risikonya serta terapi yang sesuai. ${ }^{15}$ Penelitianpenelitian sebelumnya menunjukkan bahwa faktor risiko nefropati diabetika antara lain lama menderita diabetes $\geq 15$ tahun, usia $\geq 45$ tahun, retinopati, neuropati, etnik/ras, faktor genetik, riwayat keluarga dengan penyakit kardiovaskuler, hipertensi, hiperlipidemia, jenis kelamin laki-laki, kebiasaan merokok, pengendalian glikemik yang tidak baik, ${ }^{16}$ aktifitas fisik, hiperurisemia, ${ }^{10,17}$ dan kebiasaan merokok. ${ }^{18}$

Penelitian lain menyebutkan bahwa faktor risiko utama nefropati diabetika yaitu kolesterol plasma yang tinggi, ratarata tekanan darah yang tinggi serta pengendalian glikemik yang tidak baik. ${ }^{19}$ Pada penelitian di Asia Tenggara seperti Singapura dan Malaysia mendapatkan hasil bahwa prevalensi pada wanita lebih tinggi daripada laki-laki, hal ini berbeda dengan penelitian di negara-negara lainnya seperti di Amerika, Arab Saudi maupun Afrika. Sementara itu penelitian eksperimen pada tikus menunjukkan bahwa hormon estrogen yang merupakan horman pada wanita memberikan perlindungan terhadap kerusakan ginjal (glomerulosclerosis). ${ }^{20}$ 
Untuk menjawab kontroversi ini perlu dilakukan penelitian tentang faktor risiko nefropati diabetika pada wanita. Penelitian ini bertujuan untuk mengetahui faktor-faktor risiko dari kejadian nefropati diabetika pada wanita di Indonesia yang memiliki karakteristik serupa dengan negara Malaysia dan Singapura.

\section{Metode}

Penelitian ini menggunakan desain studi kasus kontrol dengan perbandingan kasus dan kontrol 1:1. Jumlah kasus sebanyak 29 orang wanita dengan nefropati diabetika stadium 3-5 dilihat dari nilai $\mathrm{eGFR}<60 \mathrm{ml} / \mathrm{menit} / 1,73 \mathrm{~m}^{2}$ dengan proteinuria positif dan jumlah kontrol sebanyak 29 orang wanita penderita diabetes dengan nilai eGFR $>60 \mathrm{ml} / \mathrm{menit} /$ $1,73 \mathrm{~m}^{2}$ dan proteinuria negatif. Pengambilan sampel dengan teknik consecutive sampling dengan pencocokan usia antara kasus dan kontrol pada pasien rawat inap di RSUD dr Soewondo Kendal dan RSUD Tugurejo Semarang. Kasus dan kontrol yang menderita glomerulonephritis, phyelonephritis, interstilial nephritis, urinary obstruction dan congenital abnormalities dieksklusi dari penelitian. Penelitian dilakukan mulai bulan Agustus-Desember 2017.

Data responden seperti nilai kreatinin serum, ureum, tekanan darah, usia, kadar asam urat, berat badan, tinggi badan, kadar gula darah puasa, kadar kolesterol total diperoleh dari data rekam medik responden. Nilai GFR diperoleh berdasarkan rumus Crock-Gault. Tekanan darah dan kadar gula darah puasa responden dikategorikan berdasarkan ketentuan Asosiasi Diabetes Amerika (ADA) tahun 2017 yaitu tekanan darah dikategorikan ke dalam hipertensi dan normotensi dengan cut of point 130 mmHg. Sementara kadar gula darah puasa dikategorikan dengan cut of point 126 $\mathrm{mg} / \mathrm{dl}$. Kadar asam urat dikategorikan sebagai hiperurisemia jika kadar asam urat $>6,5 \mathrm{mg} / \mathrm{dl}$. Data aktifitas fisik responden diperoleh dengan wawancara berdasarkan kuesioner GPAQ (Global Phisical Activity Questionaire) dan dikategorikan sesuai anjuran WHO yaitu dengan cut of point MET (Metabolic Equivalent) 600. Kualitas tidur diperoleh berdasarkan wawancara dengan responden dan orang terdekat responden menggunakan kueioner PSQI (Pittsburgh Sleep Quality Index). Skor PSQI dikategorikan menjadi buruk jika jumlah skor $\geq 10$ dan baik skor PSQI $<10$. Data lainnya diperoleh dengan wawancara terhadap responden.

Data yang diperoleh diolah dan dianalisis menggunakan aplikasi SPSS versi 16.0 for windows. Data diolah secara multivariat menggunakan regresi logistik berganda dengan metode backwad. Penelitian ini telah memperoleh izin secara etik dari Komisi Etik Penelitian Kesehatan Fakultas Kedokteran UNDIP dan RSUP dr. Kariadi Semarang dan untuk menjaga kerahasiaan responden, maka dalam pengumpulan data tidak mencantumkan identitas responden, namun menggunakan kode tertentu.

\section{Hasil Penelitian}

Hasil penelitian menunjukkan sebagian responden merupakan ibu rumah tangga $(51,7 \%$.) dengan tingkat pendidikan terbanyak adalah SD $(62,1 \%)$.

Hasil analisis multivariat memperlihatkan faktor yang terbukti sebagai faktor risiko kejadian nefropati diabetika stadium 3-5 adalah adanya riwayat pemakaian kontrasepsi oral (OR: 7,31; 95\%CI:1,25442,716; nilai $\mathrm{p}=0,027)$, aktifitas fisik kurang (OR: 9,499; 95\%CI: 1,693-53,287, nilai $\mathrm{p}=0,011$ ), hiperurisemia (OR:9,65; 95\%CI:1,870-45,799, nilai $\mathrm{p}=0,007)$, kadar gula darah puasa $\geq 126 \mathrm{mg} / \mathrm{dL}$ (OR: 14,725 ; 95\%CI:1,487-145,846; nilai $\mathrm{p}=0,022)$ dan adanya riwayat obesitas (OR: 8,866; 95\%CI: 1,195-65,766; nilai $\mathrm{p}=0,033$ ). 
Tabel 1. Hasil analisis bivariat variabel independen terhadap kejadian nefropati diabetika stadium 3-5 pada responden wanita $(n=58)$

\begin{tabular}{|c|c|c|c|c|c|}
\hline Variabel & $\begin{array}{l}\text { Kasus } \\
(\mathrm{n}=29)\end{array}$ & $\begin{array}{c}\text { Kontrol } \\
(n=29)\end{array}$ & OR & $95 \% \mathrm{CI}$ OR & $p$-value \\
\hline \multicolumn{6}{|c|}{$\begin{array}{l}\text { Riwayat keluarga menderita } \\
\text { penyakit cardiovaskuler }\end{array}$} \\
\hline $\mathrm{Ya}$ & $4(13,8 \%)$ & $5(17,2 \%)$ & 0,77 & $0,184-3,206$ & 0,500 \\
\hline Tidak & $25(86,2 \%)$ & $24(82,8 \%)$ & & & \\
\hline \multicolumn{6}{|c|}{ Lama menderita } \\
\hline$>5$ tahun & $16(55,2 \%)$ & $10(34,5 \%)$ & 2,34 & $0,811-6,744$ & $0,093 *$ \\
\hline$\leq 5$ tahun & $13(44,8 \%)$ & $19(65,5 \%)$ & & & \\
\hline \multicolumn{6}{|c|}{ Riwayat obesitas } \\
\hline $\mathrm{Ya}$ & $11(37,9 \%)$ & $5(17,2 \%)$ & 2,93 & $0,865-9,946$ & $0,070^{*}$ \\
\hline Tidak & $18(62,1 \%)$ & $24(82,8 \%)$ & & & \\
\hline \multicolumn{6}{|c|}{ Kadar gula darah puasa } \\
\hline$\geq 126 \mathrm{mg} / \mathrm{dl}$ & $26(89,7 \%)$ & $21(72,4 \%)$ & 3,30 & $0,777-14,021$ & $0,089^{*}$ \\
\hline$<126 \mathrm{mg} / \mathrm{dl}$ & $3(10,3 \%)$ & $8(27,6 \%)$ & & & \\
\hline \multicolumn{6}{|c|}{ Kadar kolesterol total } \\
\hline$\geq 240 \mathrm{mg} / \mathrm{dl}$ & $13(44,8 \%)$ & $8(27,6 \%)$ & 2,13 & $0,714-6,374$ & $0,137 *$ \\
\hline$<240 \mathrm{mg} / \mathrm{dl}$ & $16(55,2 \%)$ & $21(72,4 \%)$ & & & \\
\hline \multicolumn{6}{|c|}{ Status hipertensi } \\
\hline $\mathrm{Ya}$ & $24(82,8 \%)$ & $17(58,6 \%)$ & 3,39 & $1,006-11,411$ & $0,041 * *$ \\
\hline Tidak & $5(17,2 \%)$ & $12(41,4 \%)$ & & & \\
\hline \multicolumn{6}{|c|}{ Kebiasaan merokok } \\
\hline $\mathrm{Ya}$ & $0(0,0 \%)$ & $1(3,4 \%)$ & - & - & - \\
\hline Tidak & $29(100,0)$ & $28(96,6 \%)$ & & & \\
\hline \multicolumn{6}{|c|}{ Status hiperurisemia } \\
\hline $\mathrm{Ya}$ & $19(65,5 \%)$ & $8(27,6 \%)$ & 4,99 & $1,631-15,252$ & $0,004 * *$ \\
\hline Tidak & $10(34,5 \%)$ & $21(72,4 \%)$ & & & \\
\hline \multicolumn{6}{|l|}{ Kualitas tidur } \\
\hline Buruk & $17(58,6 \%)$ & $20(69,0 \%)$ & 0,64 & $0,217-1,876$ & 0,293 \\
\hline Baik & $12(41,4 \%)$ & $9(31,0 \%)$ & & & \\
\hline \multicolumn{6}{|c|}{ Pola konsumsi obat } \\
\hline Tidak rutin & $13(44,8 \%)$ & $6(20,7 \%)$ & 3,12 & $0,978-9,924$ & $0,046^{* *}$ \\
\hline Rutin & $16(55,2 \%)$ & $23(79,3 \%)$ & & & \\
\hline \multicolumn{6}{|l|}{ Aktifitas fisik } \\
\hline Kurang & $16(55,2 \%)$ & $24,1 \%)$ & 3,87 & $1,260-11,880$ & $0,016^{* *}$ \\
\hline Cukup & $13(44,8 \%)$ & $75,9 \%)$ & & & \\
\hline \multicolumn{6}{|c|}{ Riwayat pemakaian } \\
\hline \multicolumn{6}{|c|}{ kontrasepsi oral } \\
\hline $\mathrm{Ya}$ & $14(48,3 \%)$ & $7(24,1 \%)$ & 2,93 & $0,957-8,988$ & $0,050 *$ \\
\hline Tidak & $15(51,7 \%)$ & $22(75,9 \%)$ & & & \\
\hline
\end{tabular}




\section{Pembahasan}

Kontrasepsi oral secara umum mengandung hormon estrogen dan progresteron. Estrogen berperan dalam regulasi dan respon beberapa komponen dari sistem renin angiotensin (RAS). Konsumsi kontrasepsi oral menghasilkan peningkatan sirkulasi komponen RAS. Konsumsi kontrasepsi oral dalam jangka lama juga berpengaruh terhadap tekanan darah. ${ }^{21}$ Hasil penelitian di Korea dan beberapa penelitian di Indonesia pada populasi wanita menunjukkan bahwa konsumsi kontrasepsi mengakibatkan kenaikan tekanan darah dan berhubungan dengan kejadian hipertensi pada wanita. 22,23

Hipertensi atau kenaikan tekanan darah sistemik mengakibatkan kenaikan pengendalian tahanan angiotensin dalam sirkulasi ginjal yang pada akhirnya mengarah pada kumulasi matriks ekstraseluler, peningkatan permeabilitas glomerulus, proteinuria dan glomerulosclerosis. ${ }^{24,25}$ Hasil penelitian ini sesuai dengan penelitian Ahmed SB et al. Dalam penelitian tersebut menunjukkan bahwa kontrasepsi oral merupakan prediktor untuk perkembangan makroalbuminuria dengan RR: 8,9.

Aktifitas fisik yang baik dan teratur merupakan perawatan non farmasi yang sangat baik bagi pencegahan dan pengelolaan DM. Aktifitas fisik cukup secara teratur meningkatkan pengambilan glukosa dalam otot, meningkatkan sensitifitas otot dan pelepasan insulin dengan perbaikan fungsi dan massa sel- $\beta$. Aktifitas fisik juga menurunkan aktifitas NADPH oksidase, sehingga memperbaiki stres oksidatif ginjal. ${ }^{26}$ Hasil penelitian ini menunjukkan bahwa aktifitas fisik yang kurang merupakan faktor risiko kejadian nefropati diabetika stadium 3-5. Hasil ini sesuai dengan penelitian Hoque et al. yang menyebutkan bahwa aktifitas fisik kurang merupakan faktor risiko nefropati diabetika (OR:1,93; 95\%CI: 1,20-3,10). ${ }^{27}$ Penelitian lain yang sesuai adalah penelitian eksperimen Ito et al. dalam percobaannya pada tikus. Dalam percobaan tersebut menunjukkan hasil bahwa latihan fisik secara teratur meru-pakan renoprotektor terhadap nefropati diabetika.

Kelima faktor yang terbukti sebagai faktor risiko tersebut bila dihitung bersama-sama sesuai rumus probability event diperoleh sebesar 99,6\%. Dengan kata lain seorang wanita penderita diabetes dengan kadar gula darah puasa $\geq 126$ $\mathrm{mg} / \mathrm{dl}$, hiperurisemia, aktifitasnya fisik kurang, mempunyai riwayat obesitas serta mempunyai riwayat pemakaian kontrasepsi oral memiliki probabilitas menderita nefropati diabetika stadium 3-5 sebesar $99,6 \%$.

Faktor lain yang terbukti sebagai faktor risiko nefropati adalah hiperurisemia. Asam urat merupakan produk akhir dari katabolisme purin yang dibentuk oleh enzim xanthine oxidase. Asam urat dalam keadaan normal berfungsi sebagai antioksidan yang berkontribusi dalam total kapasitas antioksidan dalam serum. Tetapi pada tingkat di atas $6,5-7 \mathrm{mg} / \mathrm{dl}$ pada lakilaki dan di atas $6 \mathrm{mg} / \mathrm{dl}$ pada wanita (hiperurisemia) secara paradoks asam urat berfungsi sebagai pro-oksidan. Hiperurisemia berkontribusi dalam memperburuk kelemahan ginjal yang berakibat balik meningkatkan tingkat asam urat. Dapat dikatakan tingginya asam urat merupakan kompensasi elevasi untuk melawan stress oksidatif, dimana diabetes/hiperglikemmi sendiri merupakan kondisi stres oksidatif. Hiperurisemia berkombinasi dengan gangguan metabolik lainnya secara bermakna berhubungan dengan perkembangan akhir makroalbumin. ${ }^{17}$ Penelitian Zheng $\mathrm{W}$ di Cina juga menyatakan bahwa hiperurisemia merupakan faktor yang berhubungan dengan nefropati diabetika. 
Demikian juga dengan penelitian kasus kontrol Adiga $\mathrm{US}^{28}$ dan penelitian kohort Ficociello LH. ${ }^{29}$

Hiperglikemia yang ditandai dengan tingginya kadar gula darah puasa memicu aktifasi berbagai jalur yang menstimulasi kejadian dan perkembangan nefropati diabetika, baik jalur metabolik maupun haemodinamik. Aktifasi berbagai jalur ini menyebabkan akumulasi matriks mesa-ngial, penghapusan podosit dan penebalan membran dasar glomerulus, disfungsi endothelial, atrofi tubular, fibrosis, hyolinosis arteri ginjal yang pada akhirnya terjadi kegagalan fungsi ginjal. ${ }^{30}$ Penelitian terdahulu dengan hasil yang sama antara lain penelitian Kundu et a.l di India dan penelitian Zheng $\mathrm{W}$ di China. ${ }^{17}$

Adanya riwayat obesitas terbukti sebagai faktor risiko nefropati diabetika stadium 3-5. Obesitas dan diabetes bersama-sama dengan elemen sidnrom metabolik lainnya berkontribusi besar pada perkembangan dan progresifitas penyakit ginjal. Obesitas dan diabetes meningkatkan status inflamatori derajat rendah dan berhubungan dengan infiltrasi makrofag ke ginjal. Inflitrasi makrofag ini berubah menjadi sumber mediator proinflamatori seperti TNF-a, IL-6, C-reactive protein, monocyte chemo-attractant protein-1 dan faktor hambatan migrasi makrofag.

Lemak viseral melepaskan adipokin seperti adiponektin dan leptin ke dalam sirkulasi yang juga berperan dalam patofisiologi cedera ginjal. Sebagian dari adipokin dan mediator inglamatori, vasoaktif peptida seperti Ang-II juga berkontribusi dalam glomerulopatiobesitas. ${ }^{31}$ Adanya riwayat obesitas sebagai faktor risiko nefroapti diabetika juga dibuktikan oleh penelitian Shu Meguro et al. di Jepang. Bahkan dalam penelitian tersebut menyatakan bahwa obesitas di masa lalu maupun obesitas saat sekarang merupakan faktor risiko nefropati diabetika dengan OR:2,48. ${ }^{31}$ Demikian juga hasil penelitian di Cina yang menyatakan bahwa obesitas $(\mathrm{BMI} \geq 28$ $\mathrm{kg} / \mathrm{m}^{2}$ ) meningkatkan risiko proteinuria (HR:2,87) dibandingkan dengan pasien diabetes yang kurus (BMI $18-25 \mathrm{~kg} / \mathrm{m}^{2}$ ). ${ }^{32}$.

Faktor-faktor lainnya dalam penelitian ini belum terbukti sebagai faktor risiko nefropati diabetika stadium 3-5, namun tidak dapat dikatakan bukan sebagai faktor risiko karena beberapa keterbatasan dalam penelitian ini. Lama menderita $\mathrm{DM}>5$ th dalam penelitian ini belum terbukti sebagai faktor risiko kemungkinan karena penderita DM terutama DM tipe 2 tidak menyadari bahwa mereka telah menderita DM sebelum diketahui dari hasil diagnosis dokter, sehingga kondisi glikemiknya tidak terkontrol dalam jangka lama. ${ }^{46}$

Pola konsumsi obat dan riwayat keluarga menderita penyakit kardiovaskuler dalam penelitian ini belum terbukti sebagai faktor risiko nefropati diabetika, tidak sesuai penelitian sebelumnya. Hal ini dapat terjadi karena kemungkinan penderita DM mengkonsumsi obat-obat tradisional ataupun herbal yang dalam penelitian ini tidak diketahui. Kemungkinan adanya recall bias pada faktor riwayat keluarga menderita penyakit kardiovaskuler, oleh karena responden lupa ataupun tidak mengetahui riwayat penyakit anggota keluarga terdahulu. Sehingga terdapat kemungkinan nilai OR hasil penelitian pada variabel tersebut mungkin under estimate (toward to the null) akibat bias tersebut.

Desain kasus kontrol yang digunakan dalam penelitian ini juga memungkinkan adanya bias informasi yang lain serta bias seleksi. Untuk mengatasi hal ini sudah diantisipasi dengan konfirmasi diagnosis dokter ahli dengan hasil laboratorium penderita serta cross check 
informasi/data responden terhadap anggota keluarga lainnya yang merawat penderita.

\section{Kesimpulan}

Kadar gula darah puasa $\geq 126$ $\mathrm{mg} / \mathrm{dl}$, ada riwayat pemakaian kontrasepsi oral, aktifitas fisik kurang, hiperurisemia dan ada riwayat obesitas terbukti sebagai faktor risiko kejadian nefropati diabetika stadium 3-5. Faktor-faktor tersebut merupakan faktor yang dapat diubah, sehingga wanita penderita diabetes dapat mencegah komplikasi nefropati diabetika dengan mengelola faktor-faktor tersebut secara tepat dan sedini mungkin. Apabila diperlukan konsumsi kontrasepsi oral untuk pencegahan kehamilan, maka disarankan untuk konsultasi terlebih dahulu dan rutin memeriksakan diri ke dokter.

\section{Ucapan Terimakasih}

Terimakasih kepada pihak dan pasien rawat inap di RSUD dr Soewondo Kendal dan RSUD Tugurejo Semarang yang telah memberikan ijin dan bersedia menjadi obyek penelitian dan memberikan kontribusi dalam pengumpulan data.

\section{Daftar Pustaka}

1. PERNEFRI. 2016. 9th Report Of Indonesian Renal Registry.

2. Lim AK. 2014. Diabetic Nephropathy -Complications and Treatment. International Journal of Nephrology and Renovascular Disease; 7:2.

3. Ismaili FA, Salmi IA, Maimani YA, Metry AM, Marhoobi HA, Hola A, et al. 2017. Epidemiological Transition of End-Stage Kidney Disease in Oman. Kidney International Reports;2.pp.27-35.

4. Ahmad J. 2015. Management of Diabetic Nephropathy: Recent Pro- gress and Future Perspective. Diabetes \& Metabolic Syndrome: Clinical Research \& Reviews;9.pp.343-358.

5. Salinero-Fort MÁ, Andrés-Rebollo FJS, Burgos-Lunar Cd, AbánadesHerranz JC, Carrillo-de-Santa-Pau E, Chico-Moraleja RM, et al. 2016. Cardiovascular and All-Cause Mortality in Patients with Type 2 Diabetes Mellitus in the MADIABETES Cohort Study: Association with chronic kidney disease. Journal of Diabetes and Its Complications. 2016;30(227-236).

6. Ang YG, Heng BH, Saxena N, Liew STA, Chong P-N. 2016. Annual AllCause Mortality Rate for Patient with Diabetic Kidney Disease in Singapore. Journal of Clinical \& Translational Endocrinology;4.pp.1-6.

7. Ariyanto. 2016. Beberapa faktor Risiko Penyakit Ginjal Kronik (PGK) stadium V pada Kelompok Usia di Bawah 50 Tahun. Universitas Diponegoro Thesis unpublished.

8. Thomas S, Karalliedde J. 2014. Other Complication of Diabetes: Diabetic Nephropathy. Medicine;43(1).pp.2025.

9. Atkins RC, Zimmet P. 2010. Diabetic Kidney Disease: Act Now or Pay Later. JNEPHROL;23(01).pp.1-4.

10. Al-Rubeaan K, Youssef AM, Subhani SN, Ahmad NA, Al-Sharqawi AH, AlMutlaq HM, et al. 2014. Diabetic Nephropathy and Its Risk Factors in a Society with a Type 2 Diabetes Epidemic: A Saudi National Diabetes Registry-Based Study. PLOS ONE;9(2):e88956.

11. Goñi MJ, Mozas D, Forga L, Anda E, Ibañez B, Cambra K. 2016. Incidence and Risk Factors Involved in the Development of Nephropathy in Patients with Type 1 Diabetes Mellitus: Follow Up Since Onset. Can J Diabetes;40.pp.258-263. 
12. Abougalambou SSI, Abougalambou AS, Barghash SS. 2016. A Study Evaluating the Prevalence of Nephropathy among Type 2 Diabetes Patients Attending a Teaching Hospital in Malaysia. J Clin Nephrol Ren Care;2(1).

13. Loh PT, Toh MPHS, Molina JA, Vathsala A. 2015. Ethnic Disparity in Prevalence of Diabetic Kidney Disease in an Asian Primary Healthcare Cluster. Nephrology;20.pp.216-223.

14. Soegondo S, Prodjosudjadi W, Setiawati A. 2009. Prevalence and Risk Factors for Microalbuminuria in A Cross-Sectional Study of Type-2 Diabetic Patients in Indonesia : A Subset Of DEMAND Study. Med J Indones;18.pp.124-130.

15. Pyrama R, Kansaraa A, Banerjia MA, Loney-Hutchinson L. 2012. Chronic Kidney Disease and Diabetes. Maturitas;71.pp.94-103.

16. John S. 2016. Complication in Diabetic Nephropathy. Diabetes \& Metabolic Syndrome: Clinical Research \& Reviews;10.pp.247-249.

17. Zheng W, Chen L. 2011. Factor Analysis of Diabetic Nephropathy in Chinese Patients. Diabetes \& Metabolic Syndrome: Clinical Research \& Reviews;5.pp.130-136.

18. Lim S, Chellumuthi C, Crook N, Rush E, Simmons D. 2008. Low Prevalence of retinopathy, but High Prevalence of Nephropathy Among Maori With Newly Diagnosed Diabetes-Te Wai o Rona: Diabetes Prevention Strategy. Diabetes Research and Clinical Practice;80.pp.271-274.

19. Ravid M, Brosh D, Ravid-Safran D, Levy Z, Rachmani R. 1998. Main Risk Factors for Nephropathy in Type 2 Diabetes Mellitus Are Plasma Cholesterol Levels, Mean Blood Pressure, and Hyperglycemia. Arch Intern Med;158.pp.998-1004.
20. Antus B, Hamar P, Kokeny G, Szollosi Z, Mucsi I, Nemes Z, et al. 2003. Estradiol is Nephroprotective in The Rat Remnant Kidney. Nephrology Dialysis Transplantation;18.pp.54-61.

21. The PC, Kolibu FK, Rattu AJM. 2017. Hubungan Antara Penggunaan Pil Keluarga Berencana dengan Hipertensi pada Pasangan Usia Subur di Desa Sangaji Nyeku Kecamatan Tabaru Kabupaten Halmahera Barat. PHARMACONJurnal Ilmiah Farmasi - UNSRAT;6.

22. Park H, Kim K. 2013. Associations Betwee Oral Contraceptive Use and Risks of Hypertension And Prehypertension in A Cross-Sectional Study of Korean Women. BMC Women's Health;13.

23. Pusdatin-Kemenkes. 2014. Situasi dan Analisis Keluarga Berencana. INFODATIN.

24. Parveen K, Siddiqui WA, Kausara MA, Kuddusa M, Shahida SMA, Arif JM. 2016. Diabetic Nephropathy- A Major Macrovascular Complication. International Journal of Pharmaceutical Research \& Allied Sciences;5.pp.132-158.

25. Ahmed SB, Hovind $\mathrm{P}$, Parving $\mathrm{H}-\mathrm{H}$, Rossing P, Price DA, Laffel LM, et al.2005.Oral Contraceptives, Angiotensin-Dependent Renal Vasoconstriction, and Risk of Diabetic Nephropathy. DIABETES CARE;28.

26. Lazarevic G, Antic S, Cvetkovic T, Vlahovic P, Tasic I, Stefanovic V. 2006. A Physical Activity Programme and Its Effects on Insulin Resistance and Oxidative Defense in Obese Male Patients With Type 2 Diabetes Mellitus. Diabetes Metab;32.pp.583590.

27. Hoque S., Muttalib MA., Islam MI., PA. K, Akter N, T. A. 2017. Prevalence of Nephropathy with Evaluation of HbA1c Level and other 
Associated Risk Factors in Type 2 Diabetic Patients in a Tertiary Level Hospital. KYAMC Journal;8(1).

28. Adiga US, Malawadi B. 2016. Uric acid in Type 2 Diabetes mellitus with nephropathy. International Journal of Clinical Biochemistry and Research; 3(3).pp.340-242.

29. Ficociello LH, Rosolowsky ET, Niewczas MA, Maselli NJ, M.Weinberg J, Aschengrau A, et al.2010.High-Normal Serum Uric Acid Increases Risk of Early Progressive Renal Function Loss in Type 1 Diabetes. Diabetes Care; 33.pp.1337-1343.
30. Satirapoj B, Adler SG.2014. Comprehensive Approach to Diabetic Nephropathy. Kidney Research and Clinical Practice;33.pp.121-131.

31. Maric-Bilkan C. 2013. Obesity and Diabetic Kidney Disease. Med Chin North Am;97.pp.59-74.

32. Chen H-M, Shen W-W, Ge Y-C, Zhang Y-D, Xie H-L, Liu Z-H. 2013. The Relationship Between Obesity and Diabetic Nephropathy in China. BMC Nephrology;14(69). 